\title{
Morphological and molecular evidence for the recognition of Hypoglossum sabahense sp. nov. (Delesseriaceae, Rhodophyta) from Sabah, Malaysia
}

\author{
Michael J. Wynne ${ }^{1, *}$, Mitsunobu Kamiya ${ }^{2}$, John A. West ${ }^{3}$, Susan Loiseaux-de Goër ${ }^{4}$, \\ Phaik-Eem Lim ${ }^{5}$, Ahemad Sade ${ }^{6}$, Hannah Russell ${ }^{7}$ and Frithjof C. Küpper ${ }^{7,8}$ \\ ${ }^{1}$ University of Michigan Herbarium, 3600 Varsity Drive, Ann Arbor, MI 48108, USA \\ ${ }^{2}$ Department of Ocean Sciences, Tokyo University of Marine Science and Technology, 4-5-7 Konan, Minato-ku, \\ Tokyo 108-8477, Japan \\ ${ }^{3}$ School of Biosciences, University of Melbourne, Parkville, VIC 3010, Australia \\ ${ }^{4} 11$, rue des Moguerou, F-29680 Roscoff, Brittany, France \\ ${ }^{5}$ Institute of Ocean and Earth Sciences, University of Malaya, Kuala Lumpur 50603, Malaysia \\ ${ }^{6}$ Department of Fisheries, Sabah, Kota Kinabalu 88624, Sabah, Malaysia \\ ${ }^{7}$ School of Biological Sciences, University of Aberdeen, Cruickshank Building, St. Machar Drive, Aberdeen AB24 $3 U U$, \\ Scotland, UK \\ ${ }^{8}$ Marine Biodiscovery Centre, Department of Chemistry, University of Aberdeen, Aberdeen AB24 3UE, Scotland, UK
}

Culture isolates of the genus Hypoglossum (Delesseriaceae, Rhodophyta) were obtained and their development and morphological structure over many years were followed in the laboratory. Molecular data ( $r b c \mathrm{~L}$, large subunit ribosomal DNA, and cytochrome $c$ oxidase subunit I) were obtained from these strains and evidence presented to recognize the new species: Hypoglossum sabahense from Sabah, Malaysia. Because various aspects of morphology in culture specimens differ significantly from types based on field specimens we have to rely mainly on the molecular criteria in ascribing a new taxonomic name here. This also is complicated by the major lack of molecular phylogenetic evidence for Hypoglossum and other Delesseriaceae. The 'Germling Emergence Method' and 'serendipity' are proving valuable in discovering significant new taxa from laboratory cultures which otherwise might never be known.

Key Words: COI; Delesseriaceae; Hypoglossum; LSU; Malaysia; new species; rbcL

\section{INTRODUCTION}

The world's coasts are underexplored for their macroalgal diversity. In remote locations, phycologists are often constrained by limited time in the field and / or rudimentary laboratory facilities. Also, in tropical coral reef locations, much of the actual macroalgal diversity may not be conspicuous during diving surveys due to the naturally intense grazing activity in such ecosystems (e.g., Freshwater et al. 2017). In this context, the development of the Germling Emergence Method has enabled numerous new records and discoveries of macroalgal taxa around the world (Peters et al. 2015). The approach consists of collecting substratum samples in sterile tubes
(9) $\$$ This is an Open Access article distributed under the terms of the Creative Commons Attribution Non-Commercial License (http://creativecommons.org/licenses/by-nc/3.0/) which permits unrestricted non-commercial use, distribution, and reproduction in any medium, provided the original work is properly cited.
Received April 10, 2020, Accepted May 31, 2020

* Corresponding Author

E-mail: mwynne@umich.edu

Tel: +1-734-764-8415, Fax: +1-734-998-0038 
during fieldwork or diving surveys, followed by incubation in the laboratory, and isolation of unialgal cultures, which are subsequently characterized by microscopic and molecular means (Peters et al. 2015). The methodology has enabled the recent isolation and study of Phrix spatulata (E. Y. Dawson) M. J. Wynne, M. Kamiya \& J. A. West from Easter Island (Muñoz et al. 2018), a novel Desmarestia species and a number of Ectocarpales species from the Canadian Arctic (Küpper et al. 2016) and many other cryptic macroalgae.

The genus Hypoglossum Kützing (Delesseriaceae, Rhodophyta) with 31 'accepted' species (Huisman and Lin 2018, Guiry and Guiry 2020) is widely distributed. Up to now only three species of Hypoglossum have been recorded from Malaysia: $H$. caloglossoides M. J. Wynne \& D. L. Ballantine, H. rhizophorum D. L. Ballantine \& M. J. Wynne, and H. simulans M. J. Wynne, I. R. Price \& D. L. Ballantine (Masuda et al. 2001). Morphological observations have traditionally served as the primary method for systematic investigations in the genus. Up to now molecular phylogeny in this genus has been poorly investigated. With the removal of Hypoglossum geminatum Okamura to the segregate genus Wynneophycus by Jeong et al. (2016), data for only three species of Hypoglossum are currently available in GenBank (https://www.ncbi. nlm.nih.gov). We have examined the relationships of Hypoglossum culture strains, which were isolated from Sipadan Island, Malaysia, with other Delesserioideae algae using plastid ribulose-1,5-bisphosphate carboxylase / oxygenase large subunit $(r b c \mathrm{~L})$, nuclear large subunit ribosomal DNA (LSU rDNA), and mitochondrial cytochrome $c$ oxidase subunit I (COI). Our present investigation (laboratory culture, morphology / reproduction and molecular analyses) of Hypoglossum specimens obtained in Malaysia expands the taxonomic knowledge of the genus ( $r b c \mathrm{~L}$ tree).

\section{MATERIALS AND METHODS}

Sipadan Island (Sabah, Malaysia $4.1150^{\circ} \mathrm{N}, 118.6287^{\circ}$ E) was visited by FCK in December 2007. The collected samples were incubated at the Culture Collection of Algae and Protozoa (CCAP, Oban, Scotland) at $20^{\circ} \mathrm{C}$, in Provasoli-enriched seawater (Starr and Zeikus 1987) with $\mathrm{GeO}_{2}$ to suppress diatom growth. Algal thalli started to appear after around 1 month. Two of the samples from Turtle Patch, collected on 9 and 10 December, respectively, one from $25 \mathrm{~m}$ depth (\# 091207-4) and one from $16 \mathrm{~m}$ depth (\# 101207-1), yielded foliose red algal thalli, which were further investigated by JW at the University of Melbourne starting in June 2008. The first was designated as 4731 (CCAP 1344/1, https://www.ccap.ac.uk/) and the second as 4732 (CCAP 134/2) in JW culture records and determined to belong to the genus Hypoglossum based on vegetative morphology. Primary isolation and culture research methods used by JW are explained in West (2005).

\section{Microscopy}

All photography by JW for Figs 1-3 was taken with a Zeiss GFL bright field microscope (Zeiss Australia, Sydney, Australia) and Canon G3 camera (https://www.canon.com.au/). Most images by JW were of living cultured specimens. Fig. 3A was of a specimens fixed in $5 \%$ formalin, washed in distilled water, microwaved for $10 \mathrm{~s}$ at $800 \mathrm{~mW}$ to soften filaments, then placed on slides with $1-2$ drops of $0.02 \%$ aniline blue in 50\% corn syrup with $0.1 \%$ phenol to prevent fungal growth, excess $A B$ imbibed around coverslip and twice sealed with nail polish.

For Fig. 2, the pressed herbarium specimen of cultured H. sabahense sp. nov. 4732 (sent from University of Melbourne to University of Michigan), MW soaked off blades, floated them on 2 glass slides, put on coverslips, added diluted Karo syrup around the edges, and gently warmed in an oven to dry the slides. Images were taken by MW and Pavel Klimov with a Leica DMC4500 camera attached to a Leica DM 2500 LED compound microscope (Jena, Germany) using brightfield illumination. All images were edited by SLG with Adobe Photoshop CS6 (http://www.adobe.com/au/) for publication.

\section{Molecular phylogenetic analyses}

The DNA extraction from live material was as described by Hayakawa et al. (2012). The primer sequences to amplify and sequence almost the entire $r b c \mathrm{~L}$, partial LSU, rDNA, and 5' partial COI are the same as those in Muñoz et al. (2018). The polymerase chain reactions (PCR) were conducted in a total volume of $25 \mu \mathrm{L}$ containing about 40 ng of template DNA, $0.4 \mu \mathrm{M}$ of each primer, $0.25 \mathrm{mM}$ of each dNTP, 1 PCR buffer and 0.5 units of KOD FX neo DNA polymerase (Toyobo, Osaka, Japan). The thermal profile for PCR was as follows: initial denaturation at $94^{\circ} \mathrm{C}$ for 2 min, 30 cycles at $98^{\circ} \mathrm{C}$ for $30 \mathrm{~s}, 50^{\circ} \mathrm{C}$ for $30 \mathrm{~s}$ and $68^{\circ} \mathrm{C}$ for $90 \mathrm{~s}$, and final extension at $68^{\circ} \mathrm{C}$ for $7 \mathrm{~min}$. Excess primers and dNTPs were removed from the PCR products using Exosap-it (Affymetrix, Santa Clara, CA, USA). DNA sequencing was performed by Eurofins Genomics (Tokyo, 

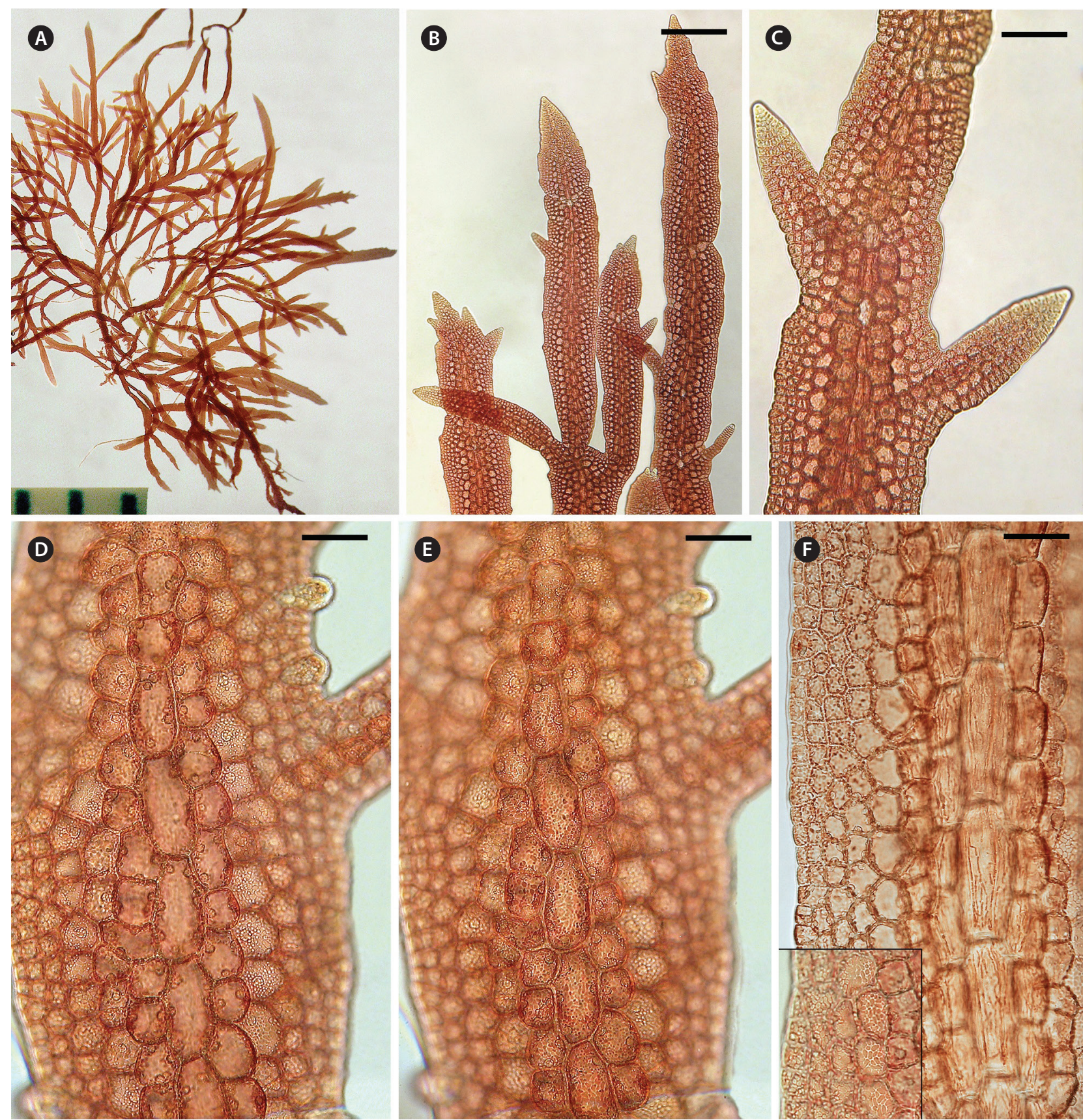

Fig. 1. Hypoglossum sabahense (4731). (A) Photo with stereoscope showing wide blades $(190-260 \mu \mathrm{m})$ in brighter light and shaker growth. (B) Blades of variable widths have clear midrib (central and periaxial cells) and flank of second and third cell rows extending to margins. Margins irregular. (C) Main blade, two lateral blades (not opposite as seen in low light) appear to arise from periaxial cell or axial cell. (D) Periaxial cells, each with peripheral 4-6 nuclei, flank cells with 1-2 nuclei. Each 4-5 $\mu \mathrm{m}$ diameter nucleus outlined by tiny refractile particles (putative starch grains). Tiny plastids variable in shape (discoid to short irregular ribbons) and size (2-3 $\mu \mathrm{m}$ width). (E) Similar to Fig. 1D, periaxial and adjacent flank cells have numerous very small plastids visible. (F) Focus on spectacular long ribbon plastids in axial and periaxial cells of thallus grown in lower light. Numerous small round plastids of wing cells at margin also shown in enlarged inset. Smaller cells at blade margins mostly uninucleate. Inset: compactly arranged peripheral plastids in blade margin cells. Scale bars represent: A, 1 mm; B, $250 \mu \mathrm{m} ; \mathrm{C}, 80 \mu \mathrm{m} ; \mathrm{D}-\mathrm{F}, 25 \mu \mathrm{m}$. 

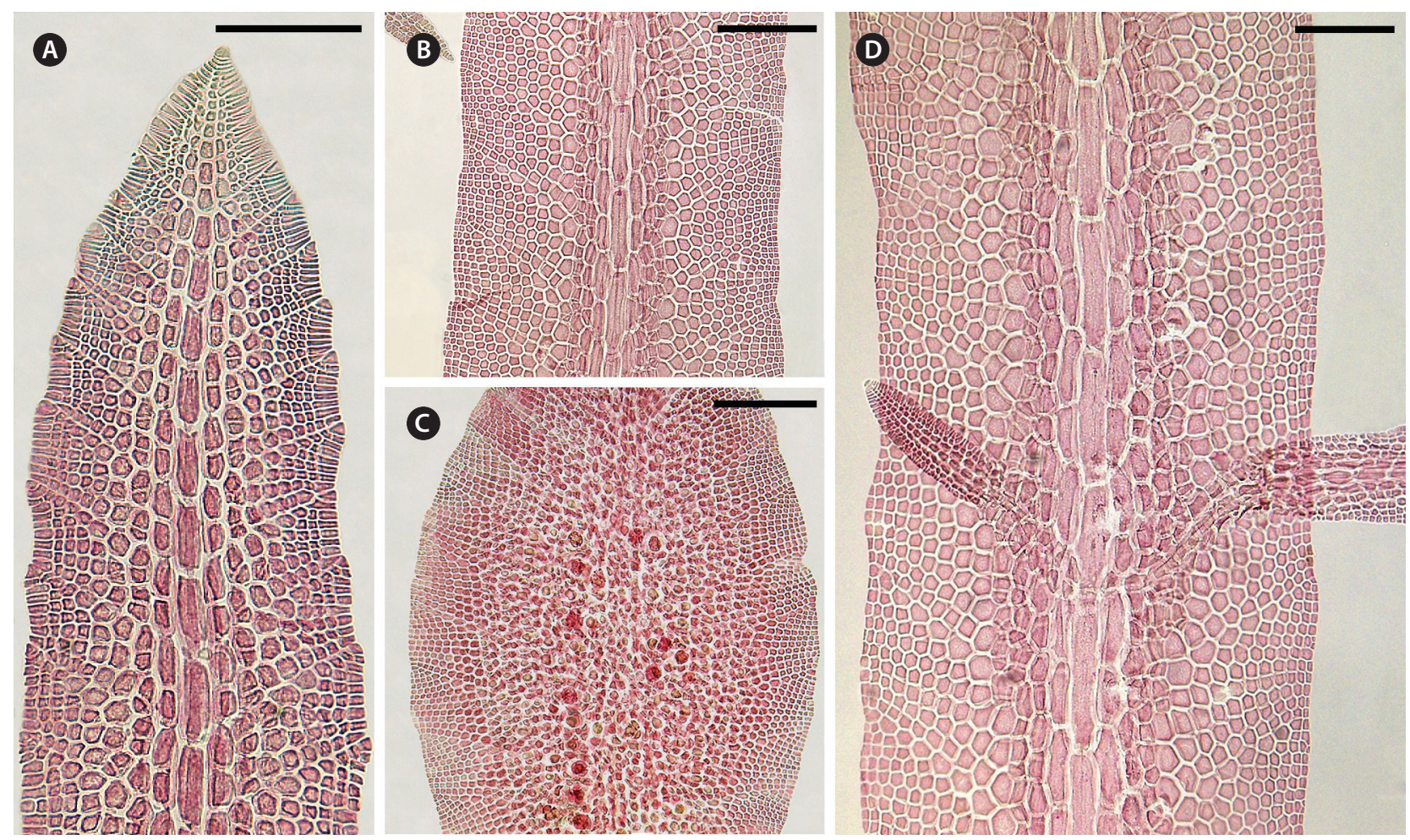

Fig. 2. Hypoglossum sabahense (4732). These images taken from HOLOTYPE in MICH. (A) Apical region of blade showing Type 1 pattern of growth. (B) Mid-region of blade with thickened midrib region. (C) Blade with tetrasporangial sorus extending over mid-region and sporangia lying in several layers. (D) Pair of branches arising from the parent blade away from the midline. Scale bars represent: A, $100 \mu \mathrm{m} ; \mathrm{B} \& \mathrm{C}, 200 \mu \mathrm{m} ; \mathrm{D}$, $150 \mu \mathrm{m}$.

Japan) and the sequences were deposited in DDBJ / ENA / GenBank (accession numbers LC541575-LC541577). The acquired LSU rDNA sequences were aligned using the MAFFT ver. 7 online application (http://mafft.cbrc. jp/alignment/software/) based on the L-INS-i algorithm with default parameters, which reflected RNA secondary structure. Adjustments of the resulting alignments were performed manually (final length was $1,926 \mathrm{bp}$ ). No indels were present in $r b c \mathrm{~L}$ (final length was $1,333 \mathrm{bp}$ ) and COI sequences (final length was $664 \mathrm{bp}$ ). The models for each codon of $r b c \mathrm{~L}$ selected by the program Kakusan4 (Tanabe 2011) are shown in Supplementary Table S1.

Maximum likelihood trees were constructed using the TREEFINDER ver. March 2011 software (http://www. treefinder.de) and were evaluated by bootstrap analysis with 1,000 replicates. For Bayesian inference analysis, Markov chain Monte Carlo (MCMC) iterations were conducted for 5,000,000 generations, with sampling every 100 generations using MrBayes 3.2.6 (http://mrbayes. sourceforge.net). Two independent simultaneous MCMC runs were performed to assess appropriate chain mixing and to ensure topological convergence (split frequency $\leq$
0.01). After inspection of convergence and stabilization with Tracer 1.5 (http://tree.bio.ed.ac.uk/software/tracer), the first $10 \%$ of generations were discarded as burnin and clade posterior probabilities were computed from the remaining trees.

\section{RESULTS}

\section{Hypoglossum sabahense M. J. Wynne, M. Kamiya \& J. A. West sp. nov. (Figs 1-3)}

Holotype. designated herein West 4732. Deposited in MICH (Herbarium of the University of Michigan, U.S.A.) [MICH 660141].

Type locality. Sipidan Island, Sabah, Malaysia $\left(4.1150^{\circ}\right.$ $\left.\mathrm{N}, 118.6287^{\circ} \mathrm{E}\right) .10 \mathrm{Dec}, 2007$. Original material collected by Frithjof Kepper at $16 \mathrm{~m}$ depth.

Etymology. "sabahense" refers to the origin of the sample, from the state of Sabah, Island of Borneo, Malaysia. Original culture CCAP No. 1344/2; further isolated by John West and grown in culture (West No. 4732) (Figs 


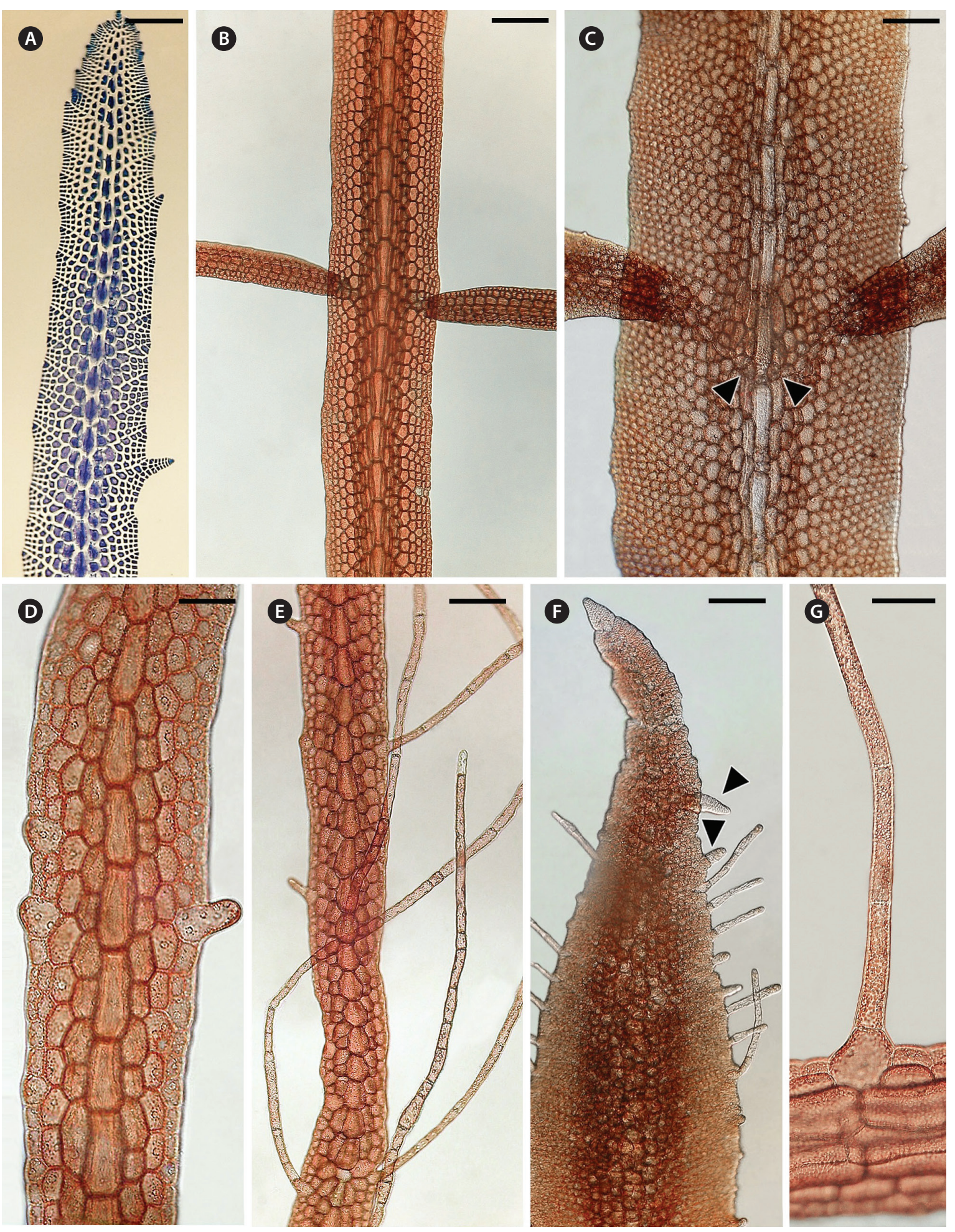

Fig. 3. Hypoglossum sabahense. (A-C \& G, 4731; D-F, 4732). (A) Blade fixed, stained with aniline blue. 2nd order cell rows extend from periaxial cells forming short lateral blades and dentate margin. 3rd order cell rows extending to blade margin. Blade $240 \mu \mathrm{m}$ wide. Grown in high light (8-9 $\mu \mathrm{mol}$ photons) and shaker. (B) Pair of opposite blades. Grown in low light (1-2 $\mu \mathrm{mol}$ photons) and stationary culture. (C) Pair of opposite blades extending from axial cell row (arrowheads). (D) Rhizoid initial with 6 nuclei, developing from wing cell at blade margin. Grown in high light (8-9 $\mu \mathrm{mol}$ photons) and shaker culture. (E) Blade grown in high light and shaker culture. (F) Blade with many rhizoids and some secondary blades (arrowheads) forming on blade margin; in low light and stationary culture. (G) Rhizoid arising from marginal wing cell, rhizoid cells $15-20 \mu \mathrm{m}$ wide, many small discoid plastids in low light and stationary culture. Scale bars represent: $A \& B, 120 \mu \mathrm{m} ; C, 50 \mu \mathrm{m} ; \mathrm{D} \& \mathrm{G}, 40 \mu \mathrm{m} ; \mathrm{E}, 60 \mu \mathrm{m} ; \mathrm{F}, 150 \mu \mathrm{m}$. 


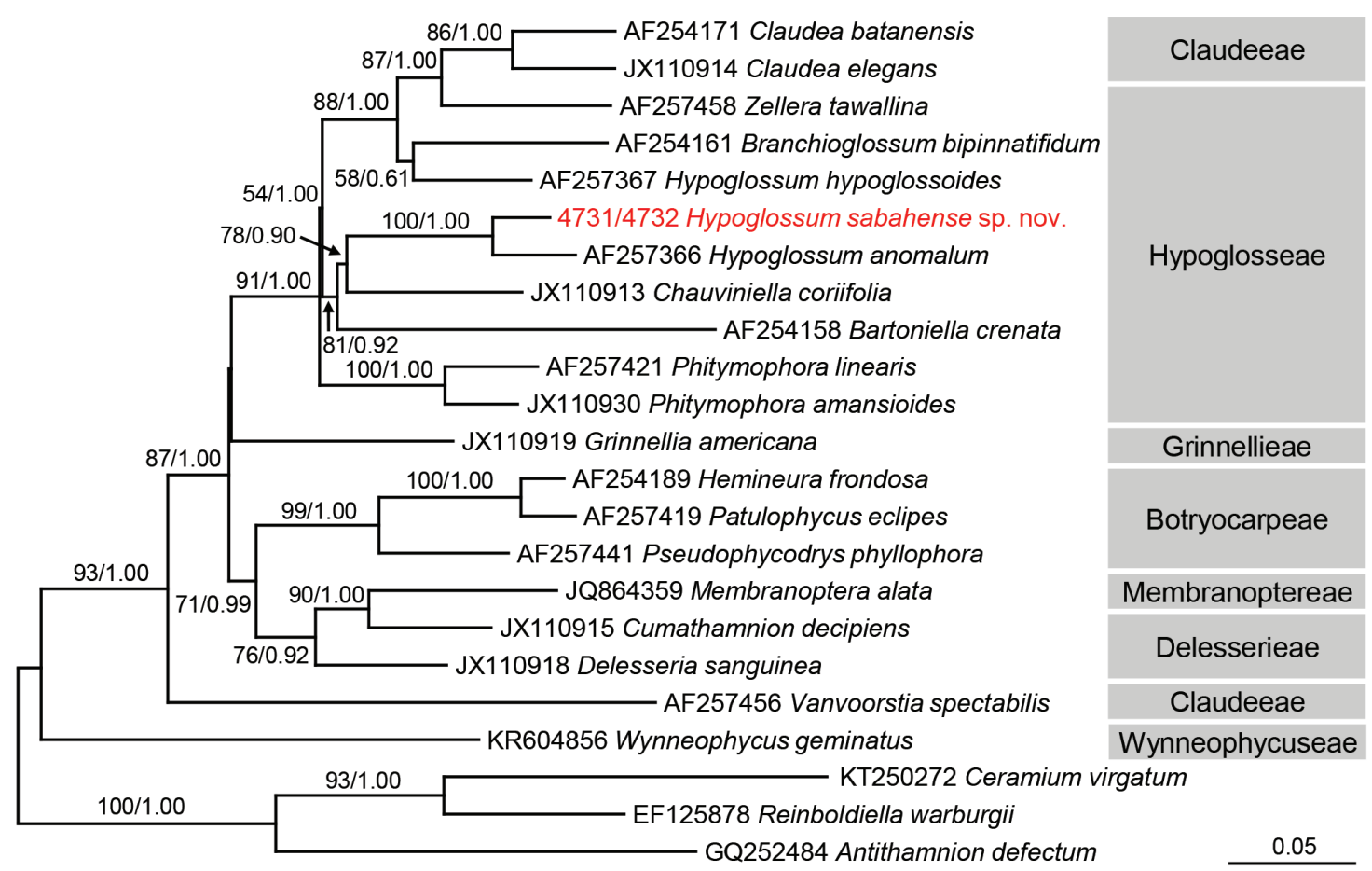

Fig. 4. Maximum-likelihood (ML) phylogeny of the Delesseriaceae inferred from partial $r b c \mathrm{~L}$ gene sequences. Bootstrap values for $\mathrm{ML}(>50 \%$, left) and posterior probabilities for Bayesian inference $(>0.5$; right) are given on each branch. Accession number or strain number is shown before each taxon name. The scale is in units of nucleotide substitutions per site.

1-3). Tetrasporangiate blades appeared in culture.

Description. Flat narrow monostromatic blades with a midrib and wings (alae) but lacking lateral veins (Figs 1A-D \& 2B-D); growth by means of a primary apical cell (Fig. 2A); apical cells of primary, 2nd and 3rd order cell rows without intercalary cell divisions (Fig. 2A \& B), all cells of 2nd order cell rows bearing 3rd order cell rows (Fig. 2A \& B) (Type 1 growth pattern according to Wynne and De Clerck 2000); vegetative blades 235-346 $\mu \mathrm{m}$ wide (Fig. 2D); tetrasporangiate blades (Fig. 2C) reaching to $378 \mu \mathrm{m}$ in width; marginal or intercalary branching from midrib (Fig. 1B-E). Lateral blades develop from the midrib usually in opposite pairs (Figs 2D, 3B \& C), equal or subequal, or less often singly, or rarely from the blade margins (Fig. 3A). The only reproductive stages observed were tetrasporangiate sori that developed under culture conditions. The sori are produced in a single median sorus per blade, forming over the midline and extending outward to cover about two-thirds of blade width (Fig. 2C); tetrasporangia lie in more than one level in the blade; individual tetrasporangia ovoid, $42-47 \mu \mathrm{m}$ long and 25-28 $\mu \mathrm{m}$ wide.

Periaxial cells each with 4-6 peripheral nuclei, flank cells with 1-2 nuclei. Each 3-4 $\mu$ m diameter nucleus en- circled by a ring of tiny refractile particles. Tiny plastids variable in shape (discoid to short irregular ribbons) and size (2-3 $\mu \mathrm{m}$ width), compactly arranged at cell periphery or in long, narrow linear rows in axial and periaxial cells (Fig. 1D-F). Rhizoidal filament initials arising from marginal blade cells (Fig. 3D-G). Rhizoid initial cells have up to 6 nuclei. Rhizoid filaments cells $15-20 \mu \mathrm{m}$ diameter, and 100-500 $\mu \mathrm{m}$ long with variable numbers of nuclei randomly scattered in the cells.

Molecular analyses. Strain 4731 was identical to strain 4732 in $r b c \mathrm{~L}$, LSU, and COI sequences. The $r b c \mathrm{~L}$ analysis (Fig. 4), including 20 Delesserioideae species and $3 \mathrm{Ce}-$ ramiaceae species (as an outgroup), revealed that Hypoglossum sabahense sp. nov. formed a clade with $H$. anomalum M. J. Wynne \& D. L. Ballantine, supported by $100 \%$ bootstrap value, and the pairwise genetic distance between the two species was $2.84 \%$ (Supplementary Table S2). The LSU analysis using 16 Delesserioideae species and 1 Ceramiaceae species (as an outgroup) showed that $H$. sabahense was included in a clade containing Hypoglosseae and Claudeeae species, although the relationship within this clade was ambiguous (Supplementary Fig. S1). The COI analysis using 19 Delesserioideae species and 3 Ceramiaceae species (as an outgroup) could 
not resolve the relationship with H. sabahense (Supplementary Fig. S2). Because we preliminarily confirmed all entities of H. hypoglossoides and unidentified Hypoglossum registered in GenBank are monophyletic in $r b c \mathrm{~L}$, LSU, and COI trees, only one sequence of H. hypoglossoides is included in each tree.

Strains 4731 and 4732 originated from 2 different samples that were collected at the same site at different depths, while the strain 4731 was collected one day earlier. For comparative observations they were grown in the same conditions. Strain 4731 grew somewhat better over the same time. The general anatomical features of both strains were the same. Photos in Fig. 1D-F are of 4731.

The low magnification views (Fig. 1A-C) show overall habitat and branching in medium light (8-9 $\mu \mathrm{mol}$ photons). Lateral blades appear to arise from axial cells. Careful cytological examination of the periaxial cells shows 4-6 nuclei around the perimeter of each cell, whereas flanking cells have 1-2 nuclei, each about $4 \mathrm{~m}$ in diameter and encircled by tiny refractile particles (Fig. $1 D-F)$. The plastids are more variable in size and internal arrangement. Periaxial and flanking cells often had numerous tiny, round to oblong (2-3 $\mathrm{m}$ in diameter) plastids compactly arranged around the cell perimeter (Fig. 1DF). Axial cells and sometimes periaxial cells had numerous long linear rows of tiny elliptic plastids around the cell perimeter (Fig. 1F). All of these features were shared by strains 4731 and 4732 .

\section{DISCUSSION}

Wynne and De Clerck (2000) described the two types of apical organization in the genus Hypoglossum. In growth of Type 1 a 3rd-order row is produced from every cell of the 2 nd-order rows, whereas in growth of Type 2 a 3rd-order row is not produced from every cell of the 2 nd-order rows. The majority of species have Type 1 organization, and that is shown by Hypoglossum sabahense. In almost all species of Hypoglossum branches arise either singly or in pairs from the axial cell row of the parent blade and immediately extend out from that parent blade. It is unusual in Hypoglossum for new branches to arise from the parent blade and not immediately arise from the midline of the parent blade instead of starting to grow within the parent blade (in opposite directions) and then to emerge somewhere between the midline of the parent blade and the blade margin. This pattern has so far been known to occur only in H. anomalum (see Wynne and Ballantine 1986) and in H. imperfectum Stegenga, R. J. Anderson \& J.
J. Bolton (see Stegenga et al. 2001). The maximum-likelihood tree based upon partial $r b c$ L gene sequence analyses, showed $H$. sabahense to be most closely related to $H$. anomalum (Fig. 4). This is not surprising in that these two species share the unusual feature of branches "lifting off" the alae at some point between the primary axial row and the blade margin. In addition, $H$. sabahense and $H$. anomalum have a similar organization of tetrasporangial sori, with the sorus occupying the central part of a blade with the sporangia lying in many layers. Also, in both species there is a thickening of the midrib region (Huisman and Lin 2018). One vegetative difference seen in $H$. anomalum is that sometimes the daughter blades do not "lift off" until they have reached the edge of the parent blade, as seen in fig. 20 of Wynne and Norris (1991). The branches in H. sabahense always "lift off" in close proximity to the center of the parent blade but not from the midline. Hypoglossum imperfectum can be distinguished because in fertile blades of that species proximal thirdorder cell rows do not reach the blade margin, a unique feature in the genus (Stegenga et al. 2001).

The molecular phylogeny in subfamily Delesserioideae is often difficult to assess. The genetic distance between $H$. anomalum M. J. Wynne \& D. L. Ballantine and $H$. sabahense is $2.84 \%$. This value is smaller than other interspecific distance, e.g., 4.04\% between Claudea batanensis Tanaka and C. elegans J. V. Lamouroux and $3.78 \%$ between Phitymophora linearis (Laing) Kylin and P. amansioides (Sonder) Womersley. However, because the genetic distance is only $2.37 \%$ between Patulophycus eclipes A. J. K. Millar \& M. J. Wynne and Hemineura frondosa (J. D. Hooker \& Harvey) Harvey, the mutation rate is different among the taxonomic groups, and we cannot simply use genetic distance as a scale to delineate species boundaries. Mutation rate is easily affected by effective population size, the degree of selection pressure, reproductive system, etc. (Drake et al. 1998, Sniegowski et al. 2000). Caloglossa intermedia M. Kamiya \& J. A. West shows an extremely long branch in the LSU tree, meaning it has a much faster mutation rate than other closely related species, but the reason is still not known (Kamiya et al. 2000). The LSU analysis could not resolve Hypoglosseae species closely related to $H$. sabahense because there is less sequence data for this tribe (8 sequences) than $r b c \mathrm{~L}$ (16 sequences). COI is known to be useful for DNA barcoding and detection of cryptic diversity (e.g., Koh and Kim 2018). However, the genetic distances of this gene (6.44-25.84\%) were much larger than those of $r b c \mathrm{~L}$ (2.37-17.69\%) and LSU (1.74-21.20\%), so the evolutionary rate of COI may be too high to unravel the relation- 
ship between / within the tribes of Delesserioideae. Consequently, $H$. sabahense made a clade with $H$. anomalum in the $r b c \mathrm{~L}$ tree but was not included in the same clade of H. hypoglossoides, the type species of Hypoglossum, in any of the present molecular trees, rejecting monophyly of this genus. Molecular analyses have been performed in only 4 out of 31 taxonomically accepted species. Thus, further morphological and molecular studies using other Hypoglossum species are required to reveal the evolutionary relationship and pursue the natural classification of this genus.

\section{ACKNOWLEDGEMENTS}

This work was supported by the UK Natural Environment Research Council (NERC, Programme Oceans 2025, WP 4.5 and grant NE/D521522/1). This work also received support from the Marine Alliance for Science and Technology for Scotland pooling initiative. MASTS is funded by the Scottish Funding Council (grant reference HR09011) and contributing institutions. FCK is grateful to faculty, staff and students at the Institute of Ocean and Earth Sciences of the University of Malaya for hosting his visits in November-December 2007 and NovemberDecember 2008. Dr. Akira F. Peters (Bezhin Rosko, 29250 Santec, Brittany, France) is acknowledged for his laboratory assistance. The University of Melbourne, School of Biosciences and the facilities provided by Prof. Geoffrey McFadden for 25 years have been invaluable for JAW's culture programs and publications since 1994.

\section{SUPPLEMENTARY MATERIALS}

Supplementary Table S1. The selected model for the maximum likelihood (ML) and Bayesian inference (BI) analyses (https://e-algae/org).

Supplementary Table S2. Pairwise genetic distances calculated using Maximum Composite Likelihood method (https://e-algae/org).

Supplementary Fig. S1. Maximum likelihood (ML) phylogeny of the Delesserioideae inferred from partial large subunit ribosomal DNA sequences. Bootstrap values for ML ( $>50 \%$; left) and posterior probabilities for Bayesian inference $(>0.5$; right) are given on each branch. The scale is in units of nucleotide substitutions per site (https://e-algae/org).

Supplementary Fig. S2. Maximum likelihood (ML) phylogeny of the Delesserioideae inferred from partial cy- tochrome $c$ oxidase subunit I gene sequences. Bootstrap values for ML ( $>50 \%$; left) and posterior probabilities for Bayesian inference $(>0.5$; right) are given on each branch. The scale is in units of nucleotide substitutions per site (https://e-algae/org).

\section{REFERENCES}

Drake, J. W., Charlesworth, B., Charlesworth, D. \& Crow, J. F. 1998. Rates of spontaneous mutation. Genetics 148:1667-1686.

Freshwater, D. W., Idol, J. N., Parham, S. L., Fernández-García, C., León, N., Gabrielson, P. W. \& Wysor, B. 2017. Molecular assisted identification reveals hidden red algae diversity from the Burica Peninsula, Pacific Panama. Diversity 9:1-38.

Guiry, M. D. \& Guiry, G. M. 2020. AlgaeBase. World-wide electronic publication, National University of Ireland, Galway. Available from: http://www.algaebase.org. Accessed Mar 18, 2020.

Hayakawa, Y. -I., Ogawa, T., Yoshikawa, S., Ohki, K. \& Kamiya, M. 2012. Genetic and ecophysiological diversity of Cladophora (Cladophorales, Ulvophyceae) in various salinity regimes. Phycol. Res. 60:86-97.

Huisman, J. M. \& Lin, S. -M. 2018. Delesseriaceae. In Huisman, J. M. (Ed.) Algae of Australia: Marine Benthic Algae of North-Western Australia. 2. Red Algae. ABRS, Canberra and CSIRO Publishing, Melbourne, pp. 437-477.

Jeong, S. J., Won, B. Y., Fredericq, S. \& Cho, T. O. 2016. Wynneophycus geminatus gen. \& comb. nov. (Delesseriaceae, Rhodophyta), based on Hypoglossum geminatum Okamura. Phycologia 55:165-177.

Kamiya, M., West, J. A., Zuccarello, G. C. \& Kawai, H. 2000. Caloglossa intermedia, sp. nov. (Rhodophyta) from the western Atlantic coast: molecular and morphological analyses with special reference to C. leprieurii and $C$. monosticha. J. Phycol. 36:411-420.

Koh, Y. H. \& Kim, M. S. 2018. DNA barcoding reveals cryptic diversity of economic red algae, Pyropia (Bangiales, Rhodophyta): description of novel species from Korea. J. Appl. Phycol. 30:3425-3434.

Küpper, F. C., Peters, A. F., Shewring, D. M., Sayer, M. D. J., Mystikou, A., Brown, H., Azzopardi, E., Dargent, O., Strittmatter, M., Brennan, D., Asensi, A. O., van West, P. \& Wilce, R. T. 2016. Arctic marine phytobenthos of northern Baffin Island. J. Phycol. 52:532-549.

Masuda, M., Abe, T., Kawaguchi, S. \& Phang, S. M. 2001. Taxonomic notes on marine algae from Malaysia. VI. Five species of Ceramiales (Rhodophyceae). Bot. 
Mar. 44:467-477.

Muñoz, L. A., Wynne, M. J., Kamiya, M., West, J. A., Küpper, F. C., Ramirez, M. E. \& Peters, A. F. 2018. Reinstatement of Phrix (Delesseriaceae, Rhodophyta) based on DNA sequence analyses and morpho-anatomical evidence. Phytotaxa 334:215-224.

Peters, A. F., Couceiro, L., Tsiamis, K., Küpper, F. C. \& Valero, M. 2015. Barcoding of cryptic stages of marine brown algae isolated from incubated substratum reveals high diversity in Acinetosporaceae (Ectocarpales, Phaeophyceae). Cryptogam. Algol. 36:3-29.

Sniegowski, P. D., Gerrish, P. J., Johnson, T. \& Shaver, A. 2000. The evolution of mutation rates: separating causes from consequences. Bioessays 22:1057-1066.

Starr, R. C. \& Zeikus, J. A. 1987. UTEX: the culture collection of algae at the University of Texas at Austin. J. Phycol. 23(Suppl):1-47.

Stegenga, H., Anderson, R. J. \& Bolton, J. J. 2001. Hypoglossum imperfectum nov. spec. (Rhodophyta, Delesseriaceae), from the South African South Coast. Bot. Mar. 44:157-162.
Tanabe, A. S. 2011. Kakusan4 and Aminosan: two programs for comparing nonpartitioned, proportional and separate models for combined molecular phylogenetic analyses of multilocus sequence data. Mol. Ecol. Resour. 11:914-921.

West, J. A. 2005. Chapter 11. Long term macroalgal culture maintenance. In Andersen, R. A. (Ed.) Algal Culturing Techniques. Academic Press, New York, pp. 157-163.

Wynne, M. J. \& Ballantine, D. L. 1986. The genus Hypoglossum Kützing (Delesseriaceae, Rhodophyta) in the tropical western Atlantic, including H. anomalum sp. nov. J. Phycol. 22:185-193.

Wynne, M. J. \& De Clerck, O. 2000. Taxonomic observations on Hypoglossum (Delesseriaceae, Rhodophyta) in the Indian Ocean and Malayan region, including the description of two new species. Cryptogam. Algol. 21:111131.

Wynne, M. J. \& Norris, R. E. 1991. Branchioglossum pygmaeum sp. nov. and new records of other delesseriaceous algae (Rhodophyta) from Natal, South Africa. Phycologia 30:262-271. 